\title{
Reviews
}

\section{The New Oxford History of New Zealand}

edited by Giselle Byrnes. Oxford University Press, South Melbourne, 2009; xvii, 738 pp. ISBN 9780195584714

Reviewed by Jock Phillips

This strange but stimulating general history of New Zealand sets out to challenge both the idea of a general history and the validity of focusing on the nation of New Zealand. The attempt to do what the editor, Giselle Byrnes, maintains should not be done, helps explain the oddities of the volume.

In the editor's preface, we are told that a 'generation of historians' are here unfolding new revisionist ways of understanding the past (Incidentally the boundaries of that generation seem surprisingly fluid, and a few of the historians, several already in retirement, must be pleasantly flattered to be considered a new generation, as must Peter Gibbons, the éminence grise - no reference to hair colour of course - behind the whole enterprise). So let's examine the editor's claims and see how the new generation have responded. The first claim is that this volume differs from previous general histories because it does not have one large master narrative. This is expressed in the deliberate avoidance of a chronological treatment. Instead the chapters are organized around six large themes each of which implicitly challenges accepted mythologies about New Zealand - People, Land and Sea; Biculturalism(s)?; Settlement and Unsettlement; Nation(s)making?; Social Laboratory?; and State Experiments?. The brackets and the question marks point to the contested nature of the myths. The themes are well-chosen and invite interesting answers. But the desire to avoid broad chronological narratives in a general history has produced a range of responses from the authors. Some, still thinking in terms of a 'general history', delivered excellent overviews bound by time and informed by the latest research which would have sat quite happily in the previous Oxford history of New Zealand. Good examples are Athol Anderson's polished summary of social and economic change in pre-European Maori society; Jim McAloon's fair and accurate survey of the course of the New Zealand economy 1792-1914 (his chapter gets dates in the title); or Geoff Bertram's 'The New Zealand Economy, 1900-2000' (again with dates) which presents a convincing three era interpretation of the twentieth-century economy. Others provide a 'general' survey but of a particular theme - John Stenhouse's powerful re-presented argument about the importance of religion in New 
Zealand society has a strong master narrative which covers two centuries; Bronwyn Labrum similarly presents a balanced survey of welfare from 1840 to 2000. Yet others took the attack on a general history as an invitation to abandon comprehensiveness and present case studies. Thus Angela Wanhalla's essay on the family spends most of its time examining two examples intermarriage of Maori and Pakeha and the Templeton farm colony for 'feeble-minded children'. The content is fascinating but in most 'general histories' each study would deserve a long paragraph at best. Similarly Judith Binney's magisterial discussion of memory and history, orality and literacy, largely drawn from Tuhoe experience is a wonderfully stimulating read with many implications for historians of other cultures, but would bewilder naïve readers looking for an understanding of nineteenth-century Maori history. The result is a series of essays each pitched at their own level and almost without exception worth reading. Yet the whole provides no 'general' history of New Zealand. There are huge absences. Maori history is very spotty in its treatment. There is no mention of the musket wars, no explanation for the New Zealand Wars. There is no discussion of Maori social history of the kind that was so richly told in Michael King's Penguin history. It is also barely credible that in the twenty-first century we still do not have Maori historians telling their own history. There is no attempt to provide an overview of Pakeha social structure either in the nineteenth or twentieth centuries - nothing to replace Erik Olssen's path-breaking essay in the earlier Oxford volume. There is very little cultural history. Apart from bits in Caroline Daley's otherwise suggestive essay 'Modernity, consumption and leisure' there is little popular culture represented (almost no reference to films, television, advertisements, photographs, cartoons etc.) and nothing at all about intellectual life - science and technology, the creative arts are nowhere to be found. Colin McCahon, Charles Goldie, Rita Angus, Allen Curnow, Ernest Rutherford are not mentioned. So we have something which proclaims itself to be in the genre of general history, but is actually an idiosyncratic series of essays. Many of the essays are well done. I particularly liked Paul Monin's tragic story of Maori and the colonial economy, Richard Hill's powerful examination of the state and Maori, and Tony Ballantyne's original approach to nineteenth-century politics. But it is false advertising to claim that the volume is in any sense a general history. If someone advertised a car, but then told you that it was a 'deconstructed' car which actually did not carry you from point to point but liked to circulate in a small area, you might be somewhat annoyed. People pick up 'general histories' because they expect to learn about the major developments of a country's history. They could legitimately demand their money back!

The second claim made by the editor and many of the authors is that this book is revisionist because it does not focus on the 'nation'. As Giselle 
Byrnes points out this is a very slippery term - sometimes it means the 'nation-state', sometimes 'national identity'; sometimes 'nationalism'. There is much to be applauded in these views. The argument that New Zealand history should not tell a Whiggish story of a young colony growing to maturity in nationhood is convincing. In the reaction against old-fashioned 'Imperial history' and in the exciting flush of looking at New Zealand history through cultural nationalist eyes, the Sinclair and post-Sinclair historians probably did put too great an emphasis on internally-driven change. They were too introspective - so any attempt to put New Zealand history into wider international contexts is to be applauded. Yet in a country with clear geographical boundaries, one powerful state and one indigenous people, the nation is an obvious unit of analysis, and it very odd to have a general history of a nation which seeks to deny the importance of the nation. Certainly the authors have had real difficulties in interpreting what was meant by the obligation to critique the nation/national identity/nationalism syndrome. Some like Roberto Rabel in his chapter on war saw the task as inviting an examination of the ideology of nationhood. I particularly liked his distinction between the mythology of the two world wars. Yet he ends up making the claim that World War Two stimulated 'the rise of a more distinctive national consciousness'. In the next chapter on sport Charlotte Macdonald interprets the instructions quite differently. She challenges the national identity syndrome by ignoring it, and suggests with some lovely material that the story of people's participation in different kinds of sport rather than the study of nationalist triumphs is a valid focus for New Zealand sports history. A number of others kick off with a revisionist statement about the dangers of national and statist history, and yet produce content which is barely altered by that perspective. David Capie's polished essay on foreign relations is a good example. Throughout Capie's excellent overview, despite his protestations, nation and state are ever-present. Bronwyn Labrum even concludes her chapter with a classic of 'nationalist history' - 'the midtwentieth-century vision of "cradle to the grave" welfare is fundamental to our national story'.

There are two particular expectations which the editor's rejection of the nation invites. One is that the history will be what she calls 'trans-national history', that is it will position New Zealand in a broader context and examine shared experiences and common features. She distinguishes this from 'comparative history' which she sees as reinforcing national differences. There are some chapters here which do reach out impressively in this direction. Athol Anderson extends the territory of Polynesian settlement to include the Sub-Antarctic islands. Damon Salesa nicely repositions New Zealand as a Pacific imperial power and cleverly integrates New Zealand's colonial rule and her response to Pacific immigration since 1960. Philippa 
Mein Smith repositions the country in the Tasman and fruitfully plays up the Australasian dimension of New Zealand life; but her focus is very much on the relations of the two countries as nation-states with concerns about trade, defence, immigration etc. This is not a Tasman world of shared social attitudes, structures or culture - no mention of the Bulletin or 'Dad and Dave' or rugby league. Katie Pickles, once she gets past the obligatory historiographical claims at the start, repositions New Zealand (where it used to be) in an imperial world and explores the meaning of gender in that imperial world-view. For the rest there is a surprising insularity to many of the chapters. The bibliographical references do not include many Australian or Canadian references, let alone African and Latin American. There is not much comparative history, which remains a most useful device since, as Giselle Byrnes admits, it helps to highlight the factors which might cause difference. I cannot see why difference is less illuminating than similarity.

The second expectation which the attack on the nation encourages is that it might replace the nation with, in Giselle Byrne's words, 'tribal, regional, class, gender, rural and urban distinctions'. That is a great ambition and I looked forward to the fruits - but the looking was largely in vain. Regional identities and sub-cultures, such a rich subject, are simply ignored. Otago has four mentions in the index; but Canterbury, Christchurch, Wellington and, dare I say it, Auckland, have none. Provincial cultures and local, let alone tribal, differences are not explored; nor is the distinction between country and city. The rise of the city and Auckland in particular, which is such a major force in twentieth-century New Zealand life, is untreated. As for class, there is one very unsatisfactory essay on the subject by Melanie Nolan, but elsewhere class differences are simply not treated - unions get two very brief mentions. The communist party, the Wobblies, the great conflicts of 1912-13 and 1951 do not appear at all. And here again class cultures are ignored - even in Nolan's chapter despite the fact that her own work Kin was particularly successful in this respect. There is nothing about New Zealand's unusual ideas of race. Gender, to be fair, gets relatively full and fair treatment.

Apart from her attack on the genre of the general history and the focus on the nation, Byrnes also claims that the book is reflective of 'recent research'. In many respects this is fair. Anyone who has read the New Zealand Journal of History for the last decade and kept reasonably abreast of the latest books will find much here that is familiar. Yet some kinds of research are not well-represented. Despite Byrnes' valid argument that the Waitangi Tribunal has produced a mountain of reports which historians need to use, there are surprisingly few references to those reports - some in Judith Binney's essay, some in Richard Hill's survey of the state and Maori, but otherwise the use 
of this material is thin indeed. There are also kinds of history which are not drawn on. Apart from Geoff Bertram's chapter which is littered with graphs, there is very little use of statistics even in chapters about the family. Apart from Chris Brickell's lively chapter on sexuality and Judith Binney's chapter again, oral history is barely used. There is a striking absence of resort to web sources, even to the wonderful Papers Past. Te Ara gets a mention but only to its book spin-offs. The volume lacks any images. It is in other words a history written overwhelmingly from published texts. Is this really the 'new history' you ask? And even in terms of the old book history, there are some problems - I noticed too many errors of fact and a poor index which confuses W.H. Oliver with his father.

All these questions come back in the end to a larger question. Who is this book for? The normal assumption is that a general history is for the general reader i.e. literate New Zealanders, visitors to the country, school pupils. As I have already suggested such people would find the text bewildering. It would not give them an overview of the history of the country. Rather the book is for other historians. If you look in the index you find that Keith Sinclair has 20 mentions, James Belich beats him with 25 (which will please him!). Yet Edward Gibbon Wakefield has three, Michael Joseph Savage five, Kate Sheppard three, Roger Douglas three, and poor old Peter Fraser is nowhere to be found! In other words this is a general history which is more concerned to debate with other historians than to analyze the development of the country. I do not have a problem with a history written for other historians, or even for history students, so long as what is written can then 'trickle down' into broader ideas for a wider audience. But I am not convinced there are many ideas here which will serve that purpose. You get a sense of a profession talking to itself. New Zealanders at this time are hungering for answers about their past - hence the phenomenal sales of Michael King's general history. They are asking big questions - what is the nature of the relationships between Maori and Pakeha, was this society ever an egalitarian society, what caused the New Zealand Wars, how have the reforms of the 1984 government affected New Zealand, what is the effect of the urbanization of New Zealand on its structure and values, what distinguishes Auckland society and culture from Canterbury's, and, dare I say it, is there anything distinctive about New Zealand and when and how did that distinctiveness emerge? You will find many interesting essays in this book, but you will not find the answers to such big questions. Instead, as the editor says, you get a past which is 'complicated', 'complex', 'diverse'. To be honest that is not good enough. If the leading historians of the country are not attempting to respond to the issues that are worrying the community, then at some point the question will be asked, do professional historians exist only to communicate to themselves. I believe intensely that history 
matters because it helps people understand the world they inhabit. I remain to be convinced that this book, a good read as it is, will, either directly or indirectly, assist in that purpose.

\section{Encircled Lands: Te Urewera 1820-1921}

by Judith Binney. Bridget Williams Books, Wellington, 2009; x, 670 pp. ISBN 9781877242441

Reviewed by Maria Bargh

In contemplating constitutional change in contemporary Aotearoa New Zealand, much could be learnt from considering the different emphasis that some Maori and non-Maori communities place on historical events and political concepts associated with these events. Ask many New Zealanders if there has ever been an area where iwi have held authority, with the recognition and sanction of the Crown, and many will answer in the negative. Which is one of the reasons why Encircled Lands is such an important book. Questions around New Zealand's constitutional arrangements continue to be debated, often without an adequate appreciation of the boundaries and arrangements that have already been experimented with.

Encircled Lands provides an intricate picture of Tuhoe attempts to retain self-governance between 1820 and 1921. From 1820 until 1896 Tuhoe experienced, amongst other things, invasions, land confiscations, uneasy peace, political divisions and survey disputes. In that time also Tuhoe continued with pre-existing, and established new, governing institutions. Notably in 1872 Te Whitu Tekau, the self-governing body for Te Urewera was established. However, by the 1890 s these political institutions were under intense pressure.

In 1896 the Crown recognized the Urewera district in the Urewera District Native Reserve Act: to 'make Provision as to the ownership and Local Government of the Native Lands in the Urewera District'.(p.398) Binney describes how:

Despite the conditions of poverty, the existence of the Urewera as an autonomous region in the later nineteenth century offered the possibility of creating a new form of political partnership. This is clearly what Tuhoe hoped ... The Act was presented in Parliament as an experiment in tribal self-government. It thus allowed for possibilities other than the common discourse of 'one nation, one law'. (pp.609-10)

The Urewera District Native Reserve Act survived over the next 26 years in the background as Te Urewera came further under the scrutiny of the Crown and their pursuit of land and other resources. The Crown also increased the political, philosophical and cultural pressure regarding land management and use, challenging the ways that Tuhoe sought to govern their 